Article

\title{
Preparation of Polyurethane Monolithic Resins and Modification with a Condensed Tannin-Yielding Self-Healing Property
}

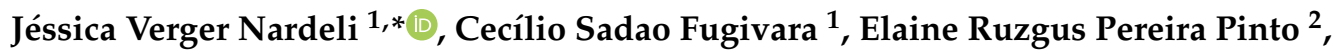 \\ Wagner Luiz Polito ${ }^{2}$, Younes Messaddeq ${ }^{2}$, Sidney José Lima Ribeiro ${ }^{2}$ and \\ Assis Vicente Benedetti ${ }^{1, *}$ \\ 1 Department of Physical-chemistry, Institute of Chemistry, São Paulo State University (UNESP), PO Box 355, \\ Araraquara 14801-970, SP, Brazil; sadao.fugivara@unesp.br \\ 2 Department of General and Inorganic Chemistry, Institute of Chemistry, São Paulo State University (UNESP), \\ PO Box 355, Araraquara 14801-970, SP, Brazil; elainerpp@gmail.com (E.R.P.P.); politowl@iqsc.usp.br (W.L.P.); \\ younes.messaddeq@copl.ulaval.ca (Y.M.); sidney.jl.ribeiro@unesp.br (S.J.L.R.) \\ * Correspondence: jeh.nardeli@gmail.com (J.V.N.); assis.v.benedetti@unesp.br (A.V.B.)
}

Received: 21 October 2019; Accepted: 13 November 2019; Published: 15 November 2019

\begin{abstract}
Resins of polyurethane were prepared from vegetable oils (crambe and castor) and modified by adding green corrosion inhibitor (condensed tannin). The oils were characterized by gas chromatography with flame-ionization detection (GC-FID), attenuated total reflectance Fourier transform infrared spectroscopy (FTIR-ATR) and thermogravimetric analysis (TGA). The reaction was monitored by characterizing the intermediate products (polyester and prepolymer). The polyester was characterized by solubility in methanol, acidity index, hydroxyl groups and FTIR-ATR, and the prepolymer was characterized by solid content, solvent content, isocyanate (NCO) groups and FTIR-ATR. The formation of PU resins was confirmed by FTIR-ATR and TGA, and the presence of tannin particles incorporated in the coating can be observed by optical microscopy (OM). The absence of the band attributed to NCO in FTIR-ATR spectra of the resins confirmed the complete reaction between polyester and prepolymer. The OM observation and a video demonstrate that Polyurethane (PU)-modified with condensed tannin resin presents self-healing effect, probably through the formation of new hydrogen bonds when in contact with deionized water. Therefore, these results open possibilities for new synthetic routes aiming at improving the very important self-healing property for protecting metals and their alloys against corrosion, extending significantly the metallic materials lifetime as previously demonstrated by our group.
\end{abstract}

Keywords: condensed tannin; self-healing; polyurethane resins; condensed tannin-modified PU resin; crambe oil; castor oil

\section{Introduction}

Modern life relies on polymers, from the materials that are used to make airplanes and cars to those with sophisticated applications in medicine. However, most polymers are derived from petrochemicals [1]. Polyurethane (PU) resin is one of the widely used materials with great potential for multipurpose applications due to its excellent physical, chemical, and mechanical properties [2-8]. Industrial processing of these compounds is still widely carried out by relying on the processing of petrochemical industries, where raw materials derived from natural gas and petroleum are limited and cannot be renewed [9]. It is important to remember that some petrochemical polymers are biodegradable, and not all bioderived polymers will be biodegraded [1]. Polyurethanes are also 
applied on metal surfaces forming barrier coatings to protect them against corrosion in aggressive environments [10,11].

In recent years there has been a growing interest in developing sustainable polymer coatings that reduce the use of petrochemical-based polymers [12]. Industrial and consumer interests in the development of green materials from abundant renewable resources have increased as they are readily available, of low cost, nontoxic and biodegradable [13]. Crambe oil from Crambe abyssinica plant fills these characteristics and is composed of different fatty acids, with specific properties, which are absent in other raw materials, being considered biocompatible and biodegradable $[14,15]$. Crambe abyssinica is a plant that can also provide a suitable raw material for higher-value products, such a, polymers, polymer additives, surfactants, personal care products and pharmaceuticals [16-18]. Castor oil is inherent biodegradable, of low cost, almost non-toxic, industrially [14,15] favorable, and easily available $[19,20]$. It is one of the most important renewable resources to produce polymers, including the preparation of polyurethanes [21], replacing petroleum-based products. Figure 1 illustrates the main fatty acids present in oils.

Oil

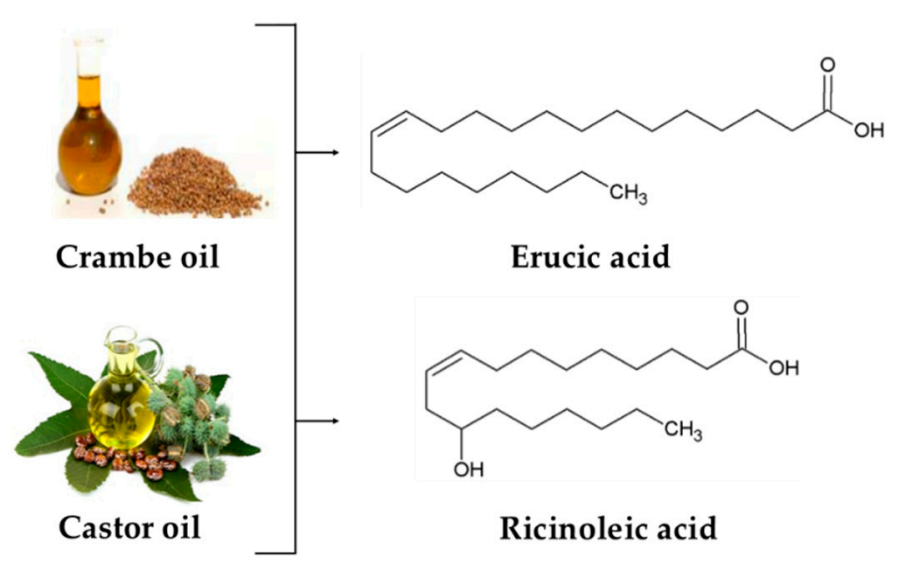

Figure 1. The main fatty acids present in oils.

Crambe oil is the most important component of polyester, and castor oil of the prepolymer.

Why and how the resins here studied were drawn? The initial studies of crambe oil-based polyurethane indicated great dependence of the electrochemical response on the nature of the resin composition [22,23], and it was also observed that after applying a scratch on the coating surface, the self-healing property was present in a resin-based coating, in which the pristine was less resistant to corrosion [24]. Conversely, the pristine that showed better corrosion resistance did not present the self-healing property [24]. This has called our attention to investigate the corrosion resistance of different coatings formulations by changing the components and their proportions. Besides the base components (crambe and castor oils, and aliphatic diisocyanate), two other components of the coating are trimethylolpropane (TMP), a crosslinking agent $[25,26]$, and phthalic anhydride (PhA) that takes part in the polyesterification and easily reacts with $\mathrm{OH}$ groups present in TMP and mono- or diglycerides. This reaction results in polyesters formation (flexible segment) $[25,26]$. Then, we choose, initially, to use two different quantities of the crosslinking agent (TMP) maintaining constant the mass of PhA, fabricating two different polyesters [24]. Then, the idea was to study the effect of the crosslinking agent on the corrosion resistant ability of the coating. The other part composing the coatings is the prepolymer, which is obtained by reacting hexamethylene diisocyanate (HDI, which contains bifunctional NCO terminal groups) with $\mathrm{OH}$ groups from different sources to produce the rigid segment. The final resin is obtained by reacting both flexible and rigid segments in a chosen polyester and prepolymer proportion. 
HDI represents the most important class of polyisocyanates used today in the fabrication of polyurethane resins. Resins prepared with aliphatic diisocyanates provide excellent resistance to chemicals and to yellowing $[27,28]$. This is one of the main advantages of using aliphatic diisocyanates compared to aromatic ones, whose resins undergo oxidation easier, especially when exposed to UV light, than those prepared from aliphatic diisocyanates [29]. HDI can react with many chemicals [30] and in our system the main reactions of HDI to form the prepolymer are drawn in Figure 2.

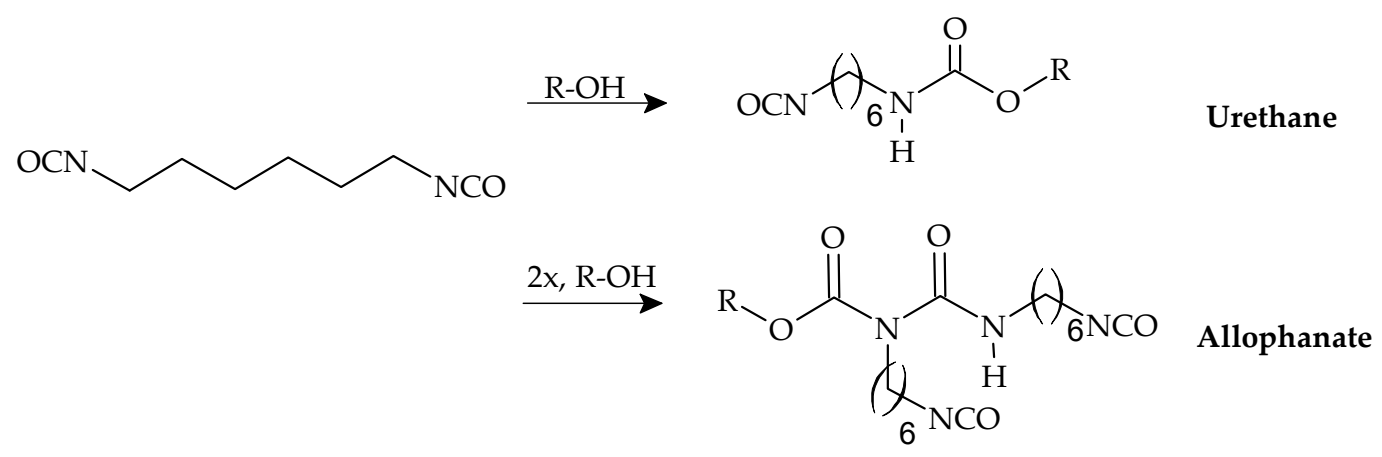

Figure 2. Main reactions of prepolymer in the curing process [30], modified by the authors.

In order to increase the amount of hydroxyl groups in the final resin structure and develop a smart coating, condensed tannin was incorporated into the synthesis.

Tannin in vascular plants occurs as two types, condensed and hydrolysable. Hydrolysable tannin is made up primarily of gallic acid while condensed tannin is made up from three-ring flavanols [31] and is largely used to produce adhesives, foams, biofoams [32] and many tannin-based polymers using different hardeners [33]. Tannins are natural polyphenolic antioxidants [34] and contain multiple adjacent hydroxyl groups and exhibit specific affinities for many metal ions [34]. Tannin, when added to the electrolyte or in the primer, protects metallic surfaces against corrosion [35-41], and when encapsulated tannin was added to sol-gel films of methyltrimethoxysilane and tetraethylorthosilicate, but when directly added to the sol-gel film was leaching [42]. However, when condensed tannin was directly incorporated to the crambe oil-derived polyurethane resin have conferred the self-healing property to the coating and tannin leaching was negligible [43], which attributed to this material excellent protection of AA2024 alloy against corrosion in chloride solutions.

This work aims at formulating, preparing and characterizing PU resins unmodified [22,24] and modified with condensed tannin used as corrosion inhibitor of aluminum and aluminum alloys [43], and demonstrating the self-healing effect in the condensed-tannin-modified PU resin monoliths, which significantly increases the service life of corrosion-resistant coatings with artificial defects or damaged in service. The investigation of self-healing property in monoliths when compared to the coated substrate may give insight about the influence of the metallic substrate in the corrosion resistance performance of the coating.

\section{Materials and Methods}

\subsection{Materials}

Crambe oil (CO) provided by Foundation Mato Grosso do Sul (Campo Grande, Brazil) [44], castor oil (CAO) provided by Asher ${ }^{\circledR}$ (São Carlos, Brazil), condensed tannin species extracted from mimosa (Acacia mearnsii) [45,46] provided by TANAC ${ }^{\circledR}$ (Montenegro, Brazil). Trimethylolpropane (TMP, CAS number 77-99-6), phthalic anhydride (PhA, CAS number 85-44-9), butylated hydroxyl toluene (BHT, CAS number 128-37-0), lithium hydroxide ( $\mathrm{LiOH}, \mathrm{CAS}$ number 1310-65-2), propylene glycol (PG, CAS number 57-556), n-butyl acetate (BA, CAS number 123-86-4), ethyl glycol acetate (EGA, CAS number 111-15-9), hexamethylene diisocyanate (HDI, CAS number 212-485-8), stannous octoate (SO, CAS 
number 301-10-0) were used to prepare the organic resin. All reagents and solvents are analytical grade and were purchased from Sigma-Aldrich ${ }^{\circledR}$ (St. Louis, MO, USA).

\subsection{Characterization Techniques}

\subsubsection{Raw Materials}

Quantification by Gas Chromatography with Flame-Ionization Detection (GC-FID)

For this analysis, both vegetable oils were transesterified to form methyl esters (Scheme 1). The reactions were carried out in a flask equipped with a reflux condenser, and the raw material $(50 \mathrm{~g})$ that remained under stirring and heating was introduced until reaching a temperature of $70{ }^{\circ} \mathrm{C}$. In parallel, amounts of potassium hydroxide catalyst $(\mathrm{KOH}, 0.5 \mathrm{~g})$ and methanol $\left(\mathrm{CH}_{3} \mathrm{OH}, 91 \mathrm{~mL}\right)$ were added and homogenized. The reaction was kept under constant stirring at a temperature of $(70 \pm 5){ }^{\circ} \mathrm{C}$ for $3 \mathrm{~h}$ at reflux. At the end of the reactions, the product was separated from glycerol, excess methanol, catalyst and other soluble impurities in the polar environment, followed by washing of the methyl esters and subsequently analyzed/quantified by gas chromatograph equipped with a flame ionization detector (GC-FID). The methyl esters were dissolved in heptane and the analysis performed in a Shimadzu GC-2010 GC-FID (Kyoto, Japan) and a Zebron ZB -5HT column $(30 \mathrm{~m} \times 0.32 \mathrm{~mm} \times 10 \mu \mathrm{m})$, helium (carrier gas with velocity $54.0 \mathrm{~cm} \mathrm{~s}^{-1}$ ), stationary phase $5 \%$ phenyl and $95 \%$ dimethyl polycyclohexanol No. 314134.<smiles>[R]C(=O)OCC(COC([R])=O)OC([R])=O</smiles><smiles>[R]C(=O)OC</smiles>

triglycerides (crambe oil or castor oil)

Scheme 1. Transesterification of vegetable oils to form methyl esters.

Attenuated Total Reflectance Fourier Transform Infrared Spectroscopy (FTIR-ATR)

Raw materials (crambe and castor oil), the intermediates (polyester, prepolymer) and final products (PU resin, and PU-modified resin) were analyzed by means of a FTIR-ATR using a Vertex70 Bruker spectrophotometer (Billerica, MA, USA) with an Attenuated Total Reflectance accessory (scans $=64$, energy scanning from 590 to $4000 \mathrm{~cm}^{-1}$, resolution $=4 \mathrm{~cm}^{-1}$ ).

\subsubsection{Polyester}

\section{Hydroxyl Groups}

This analysis confirms whether the modification reaction of crambe oil was successful by determining the quantity of hydroxyl groups added to the chemical structure. The quantity of hydroxyl groups was determined in triplicate according to ASTM E222 [47] and calculated using Equation (1):

$$
\mathrm{I}_{\mathrm{OH}}=\frac{\mathrm{V}_{\mathrm{B}}+\left(\frac{\mathrm{m}_{\mathrm{sm}} \times \mathrm{V}_{\mathrm{IAl}}}{\mathrm{m}_{\mathrm{IAl}}}\right)-\mathrm{V}_{\mathrm{KOH}}}{\mathrm{m}_{\mathrm{sm}}} \times 56.1
$$

where $\mathrm{V}_{\mathrm{B}}=$ volume of alcoholic $\mathrm{KOH}$ standard solution necessary to titrate the blank (oil) (mL); $\mathrm{V}_{\mathrm{KOH}}=$ volume of the alcoholic $\mathrm{KOH}$ standard solution necessary to titrate the sample $(\mathrm{mL})$; 
$\mathrm{V}_{\mathrm{IAl}}=$ volume of the standard solution of alcoholic $\mathrm{KOH}$ spent on $\mathrm{I}_{\mathrm{Al}}(\mathrm{mL}) ; \mathrm{m}_{\mathrm{sm}}=$ sample mass $(\mathrm{g}) ; \mathrm{m}_{\mathrm{IAl}}=$ sample mass $(\mathrm{g})$ for the determination of index acid $\left(\mathrm{I}_{\mathrm{AI}}\right)$.

\subsubsection{Prepolymer}

\section{Solid Content and Solvent Content}

The solid content was determined for the prepolymer and indicates the quantity of remaining reagent after the solvent curing and evaporation process $[25,26]$. For analysis, Petri dishes were used. Each Petri dish was weighed empty followed by the addition of an amount of prepolymer $(\sim 1 \mathrm{~g})$. The samples were then kept at room temperature $(25 \pm 5){ }^{\circ} \mathrm{C}$ for $24 \mathrm{~h}$. The calculation was performed according to Equations (2) and (3).

$$
\text { Solid content }(\%)=\frac{\text { dry prepolymer mass }(\mathrm{g})}{\text { mass of the liquid prepolymer }(\mathrm{g})} \times 100
$$

$$
\text { Solvent content }(\%)=100-(\text { solid content })
$$

\section{NCO Groups}

The quantity of NCO groups was determined in triplicate according to ASTM D2572 [48,49] and calculated according to Equation (4). The NCO groups defines the mass percentage of isocyanate groups that are available to react with polyester, water, etc.

$$
\% \mathrm{NCO}=\frac{[(\mathrm{B}-\mathrm{V}) \times \mathrm{N} \times 0.0420]}{\mathrm{W}} \times 100
$$

where $\mathrm{B}=$ volume of $\mathrm{HCl}$ solution used to titrate the blank (without the sample) $(\mathrm{mL}) ; \mathrm{V}=$ volume of $\mathrm{HCl}$ solution used to titrate the sample $(\mathrm{mL}) ; \mathrm{N}=$ concentration of $\mathrm{HCl}$ solution; $\mathrm{W}=$ sample mass $(\mathrm{g})$.

\subsubsection{PU Resin and PU-Modified Resin}

PU resin and PU-modified resin were characterized by FTIR-ATR.

\section{Raman Spectroscopy}

All the samples were also analyzed by solid state Raman using a Fourier transform Raman spectrometer (Bruker RAMII model, Billerica, MA, USA). For each Raman spectrum, 200 scans were performed in the range of $4000-500 \mathrm{~cm}^{-1}$ with a resolution of $4 \mathrm{~cm}^{-1}$. The source of radiation was a leisure with a wavelength of $1064 \mathrm{~nm}$ and a power of $100 \mathrm{~mW}$ with acquisition time of $6 \mathrm{~min}$.

Thermogravimetric Analysis (TGA)

The thermal stability of raw materials (vegetable oils) and resins (PU and PU-modified) was analyzed by thermogravimetric analyzer (TGA, Hitachi STA 7200, Tokyo, Japan), performed from $25^{\circ} \mathrm{C}$ to $550{ }^{\circ} \mathrm{C}$ at $10{ }^{\circ} \mathrm{C} \mathrm{min}-1$ under nitrogen gas at a flow rate of $100 \mathrm{~mL} \mathrm{~min}{ }^{-1}$.

\section{Optical Microscopy (OM)}

The surface of resins with an artificial scratch (size $1000 \mu \mathrm{m} \times 60 \mu \mathrm{m}$ ) using a scalpel blade was recorded during $4 \mathrm{~h}$ of immersion in a thin layer of deionized water using a system [50] that allows to monitor the surface with a stereomicroscope Carl ZEISS Jena (Oberkochen, Germany) coupled to a computer and TOP VIEW ${ }^{\circledR}$ software (SPECwise, Inc., West Palm Beach, FL, USA). 


\section{Results and Discussion}

\subsection{Characterization of Raw Material}

\subsubsection{Quantification by Gas Chromatography with Flame-Ionization Detection (GC-FID)}

Results from GC-FIG of methyl esters (crambe and castor) are shown in Table 1. The results suggest that the major component for crambe methyl esters is derived mainly from erucic acid (13-cis-docosenoic acid), while for castor methyl esters, the largest component is ricinoleic acid (12-hydroxy-9-cis octadecenoic).

Table 1. Results of compositional analysis profile of the methyl esters of crambe and castor oils.

\begin{tabular}{cccc}
\hline \multirow{2}{*}{ Correspondent Fatty Acid } & Chemical Name & Crambe & Castor \\
\cline { 3 - 4 } & & 3.5 & \multicolumn{2}{c}{$\mathbf{( \% )}$} \\
\hline Palmitic acid & hexadecanoic acid & 1.7 & 0.9 \\
Stearic acid & octadecanoic acid & 15.1 & 3.6 \\
Oleic acid & cis-9-octadecenoic acid & - & 94.9 \\
Ricinoleic acid & 12-hydroxy-9-cis octadecenoic acid & 7.4 & 6.2 \\
Linoleic acid & cis-,cis-9,12-octadecadienoic acid & 5.1 & 0.7 \\
Linolenic acid & cis,9,12,15-octadecatrienoic acid & 1.9 & - \\
Arachidic acid & eicosanoic acid & 6.9 & 0.5 \\
Gadoleic acid & cis,9-eicosenoic acid & 0.4 & - \\
- & 11,14-Eicosadienoic acid & 3.6 & - \\
Behenic acid & docosanoic acid & 52.9 & - \\
Erucic acid & 13-cis-docosenoic acid & 1.1 & - \\
DHA & tetracosanoic acid & 5.2 & - \\
Lignoceric acid & cis-15-tetracenoic acid & 2.3 & - \\
- & &
\end{tabular}

\subsubsection{Attenuated Total Reflectance Fourier Transform Infrared Spectroscopy (FTIR-ATR)}

Figure 3 illustrates the FTIR-ATR spectrum for crambe oil, castor oil and tannin and the main attributions of the different bands in FTIR-ATR (normalized intensity of bands) stand out.

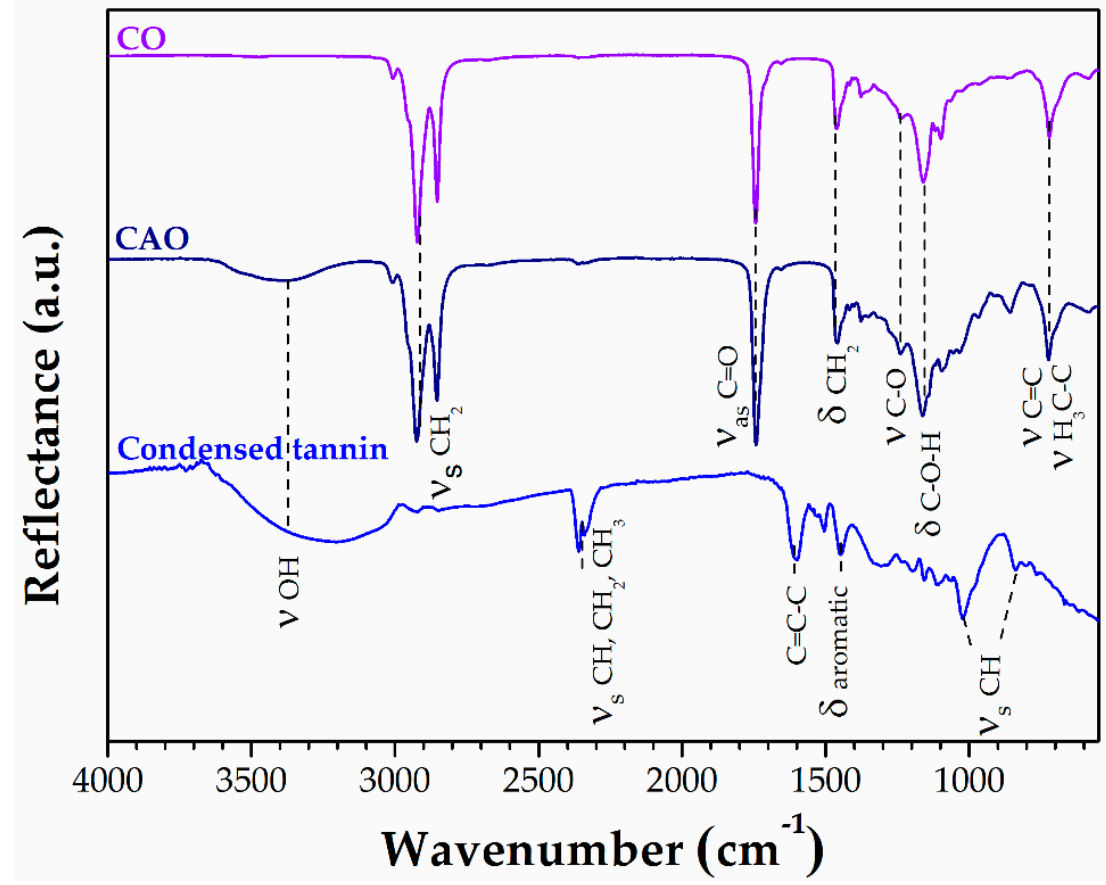

Figure 3. FTIR-ATR spectra for the crambe oil, $\mathrm{CO}(-)$, castor oil, $\mathrm{CAO}(-)$ and condensed tannin $(-)$. 
The FTIR-ATR spectrum of crambe oil evidences the absence of -OH band, as expected because crambe oil has no hydroxyl in its structure; the spectrum for castor oil evidences the presence of $-\mathrm{OH}\left(3425 \mathrm{~cm}^{-1}\right)$. In the case of condensed tannin, the absence of band $\mathrm{C}=\mathrm{O}\left(\sim 1700 \mathrm{~cm}^{-1}\right)[40,43]$ confirms that the structure is a condensed (condensed tannin) [51] and contributes to the insertion of $\mathrm{OH}\left(\sim 3340 \mathrm{~cm}^{-1}\right)$ that favors the self-healing effect when the resin is applied to protect aluminum alloys [43].

\subsubsection{Thermogravimetric Analysis (TGA)}

Representative dynamic thermogravimetric analysis (TGA) results of crambe oil and castor oil are shown in Figure 4.

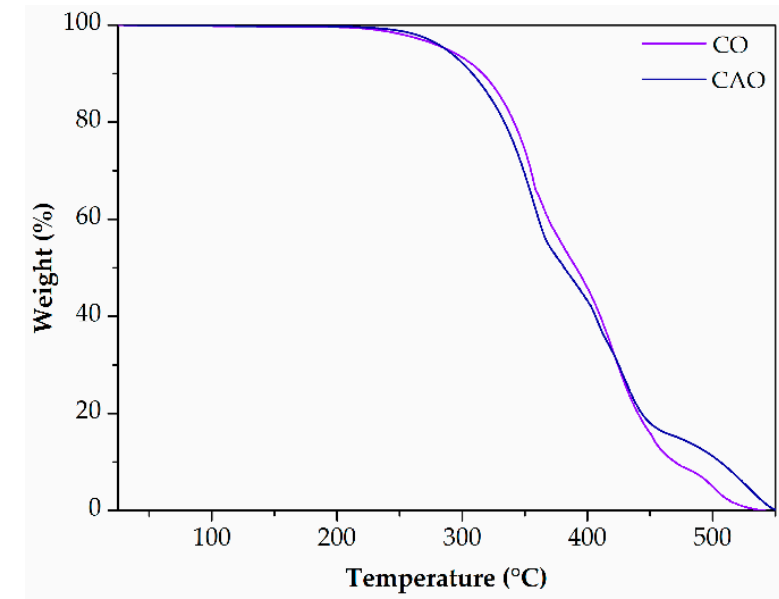

(a)

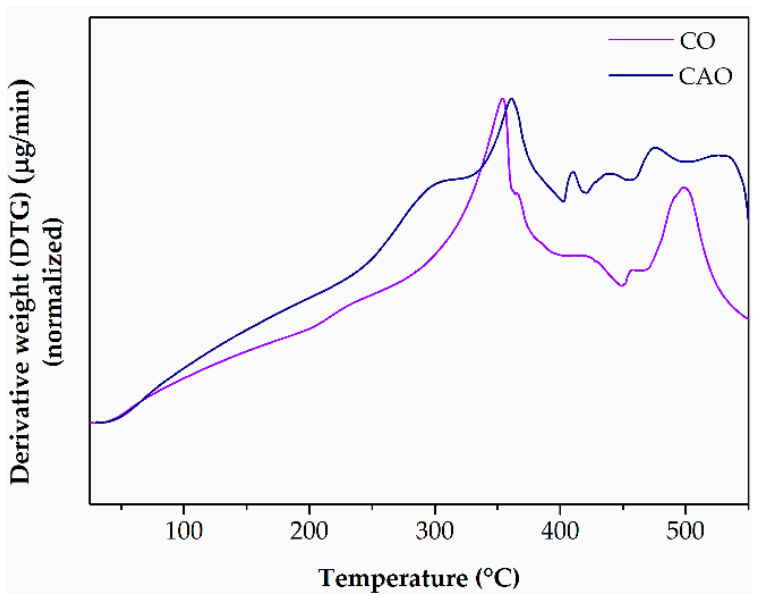

(b)

Figure 4. TGA weight loss (a) and derivatives of TGA data (b) of crambe oil, $\mathrm{CO}(-)$, castor oil, CAO $(-)$.

Crambe and castor oils exhibit no appreciable weight loss before $250{ }^{\circ} \mathrm{C}$, indicating good thermal stability. The most stable raw material was crambe oil-CO $\left(300^{\circ} \mathrm{C}\right)$, followed by castor oil-CAO $\left(294.4^{\circ} \mathrm{C}\right)$. Both oils presented thermal decomposition in three consecutive stages between $245-535^{\circ} \mathrm{C}$ (crambe oil-CO) and $240-555^{\circ} \mathrm{C}$ (castor oil-CAO). These values indicate high purity of oils, with no presence of inorganic compounds. DTG curves present a series of exothermic events, which are attributed to the oxidative degradation of organic matter (oil structure).

\subsection{Main Chemical Reactions for the Polyester and Prepolymer Preparation and Products Characterization}

\subsubsection{Polyester Preparation}

Polyester was produced by reacting a vegetable oil and oxygenated solvents based on literature with modifications [43,52,53]. Crambe oil (CO, $1995.2 \mathrm{~g})$, trimethylolpropane (TMP, $804.6 \mathrm{~g})$, butylated hydroxyl toluene (BHT, $1.0 \mathrm{~g}$ ) and lithium hydroxide $(\mathrm{LiOH}, 0.50 \mathrm{~g})$ under stirring and heating at $240{ }^{\circ} \mathrm{C}$ for $5 \mathrm{~h}$ in $\mathrm{N}_{2}$ atmosphere, and glycerin (a by-product) was removed during the reaction with Dean-Stark (Figure $5 \mathrm{a}$ and Scheme 2). The reaction progress was monitored by the methanol solubility test ( $3 \mathrm{~mL}$ methanol/1 $\mathrm{mL}$ polyester) and acidity index $(\mathrm{mg} \mathrm{KOH} / \mathrm{g}$ of polyester). When the polyester was totally solubilized in methanol and the acidity index was lower than 30 , the reaction was completed, and the synthesis stopped. After $5 \mathrm{~h}$ of reaction, the temperature was lowered to $150^{\circ} \mathrm{C}$ and phthalic anhydride (PhA, 888.6 g) was added under stirring and heating at $150{ }^{\circ} \mathrm{C}$ for $2 \mathrm{~h}$ in $\mathrm{N}_{2}$ atmosphere (Figure 5a and Scheme 3). 


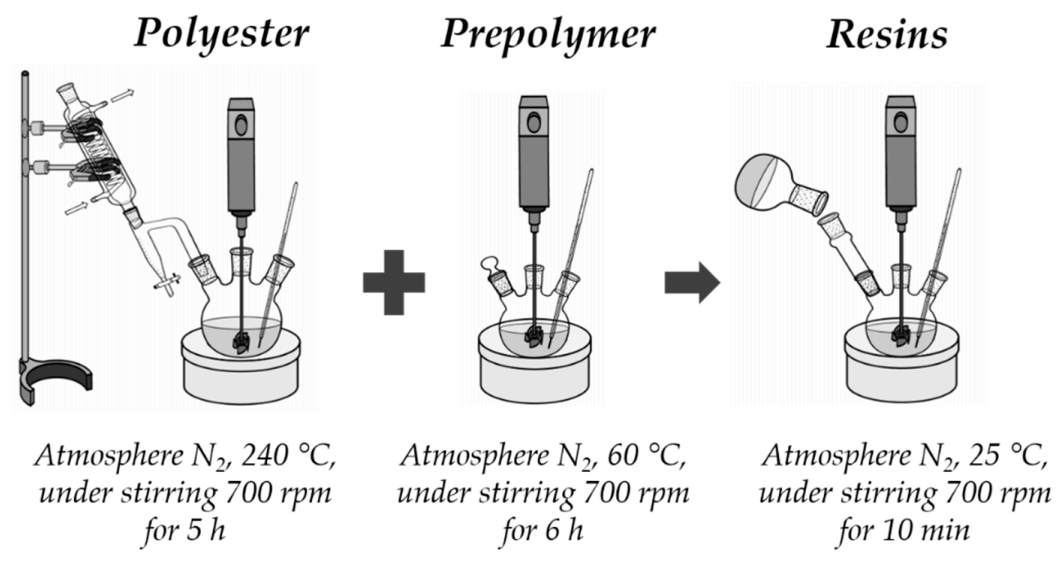

(a)

(b)

(c)

Figure 5. Reaction system for: (a) polyester, (b) prepolymer and (c) PU and PU-modified resins.
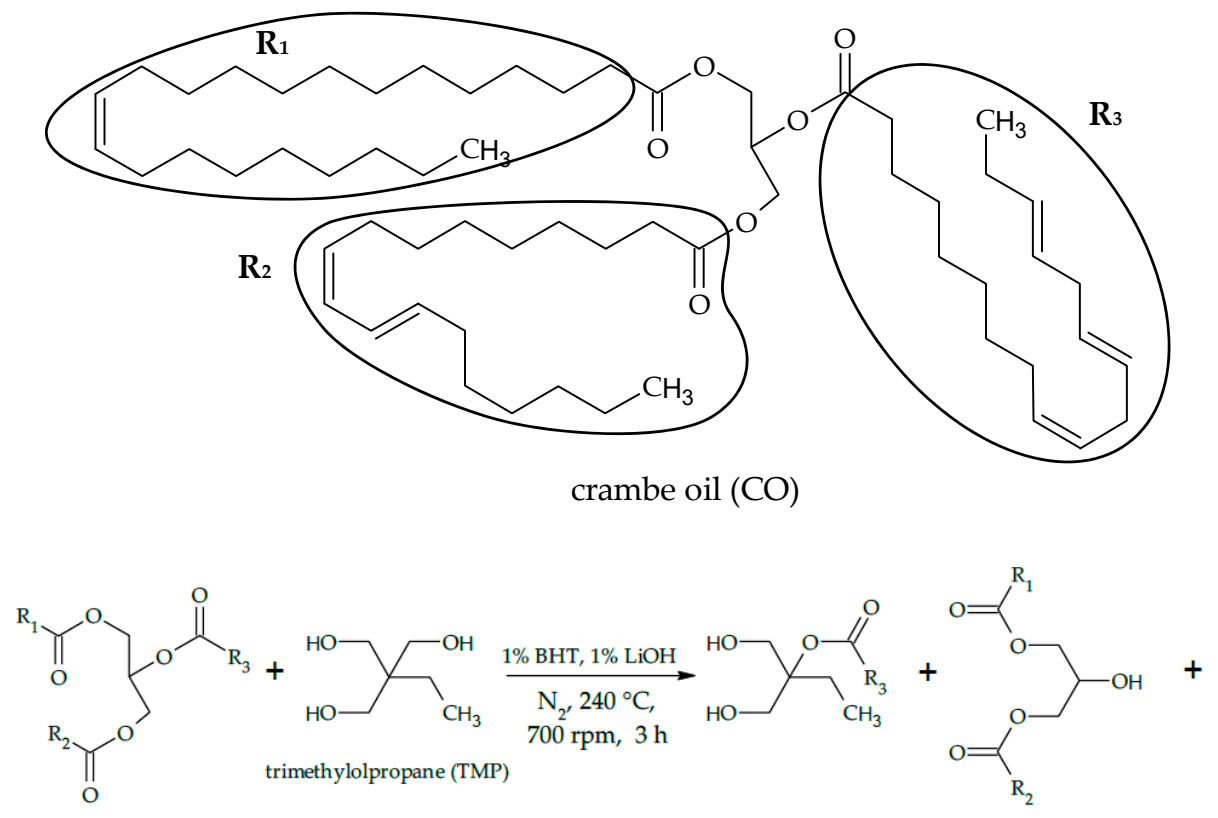

crambe oil (CO)<smiles></smiles>

Scheme 2. First step of modification of crambe oil.<smiles>[R]C(=O)OCC(COC([R1])=O)O[CH2+]</smiles><smiles>[R]C(=O)OCC(COC([R])=O)OC(=O)c1ccccc1C(=O)O</smiles>

Scheme 3. Reaction that occurs with all products formed in Scheme 2, especially with the -OH for polyester formation. 


\subsubsection{Prepolymer Preparation}

Prepolymer was produced by reacting a vegetable oil and oxygenated solvents based on literature with modifications [43]. The prepolymer was prepared with castor oil (CAO, $250.6 \mathrm{~g})$, trimethylolpropane (TMP, $93.86 \mathrm{~g}$ ), butylated hydroxy toluene (BHT, $4.40 \mathrm{~g}$ ), propylene glycol (PG, $24.34 \mathrm{~g}$ ), n-butyl acetate (BA, $889.78 \mathrm{~g}$ ), ethyl glycol acetate (EGA, $383.22 \mathrm{~g}$ ), hexamethylene diisocyanate (HDI, $1046.16 \mathrm{~g}$ ) under stirring and heating at $60^{\circ} \mathrm{C}$ for $6 \mathrm{~h}$ in $\mathrm{N}_{2}$ atmosphere (Figure $5 \mathrm{~b}$ and Scheme 4).<smiles>CCCCCCC(O)C/C=C\CCCCCCCC(=O)OCC(COC(=O)CCCCCCC/C=C\CCC(O)CCCCCC)OC(=O)CCCCCCC/C=C\CC(O)CCCCCC</smiles><smiles>CCCCOC(C)=O</smiles><smiles>CCC(CO)(CO)CO</smiles><smiles>CC/C=C\CC(CCC)CCOC(=O)N(CCCC)CCOC(=CCCC)CCCCC</smiles><smiles></smiles>

hydrogen bonds formed in the polyurethanes

Scheme 4. Prepolymer obtaining reaction. 


\subsubsection{Characterization of Polyester and Prepolymer}

Hydroxyl Groups, Solid Content, Solvent Content, and NCO Groups

Table 2 shows the physicochemical properties for the polyester (hydroxyl groups) and prepolymer (solid content and solvent content, NCO groups).

Table 2. Physicochemical properties of polyester and prepolymer.

\begin{tabular}{cccc}
\hline \multicolumn{2}{c}{ Properties } & & \\
\hline Polyester & & Prepolymer & \\
\hline Hydroxyl groups (mg KOH/g sample) & 151.6 & Solid content (\%) & 56.1 \\
\hline & & Solvent content (\%) & 43.8 \\
& & NCO groups (\%) & 6.26 \\
\hline
\end{tabular}

Crambe oil has no hydroxyl in its chemical structure, so the structure is modified by transesterification with trimethylolpropane (TMP). The hydroxyl groups $\left(\mathrm{I}_{\mathrm{OH}}\right)$ are all considered hydroxyls present in the chemical structure of the modified polyester. Thus, the result of the hydroxyl groups (151.6 $\mathrm{mg} \mathrm{KOH} / \mathrm{g}$ sample) confirms the modification of the raw material (crambe oil). According to the literature [26] the greater the quantity of free hydroxyls, the more the reaction medium is conducive to carrying out chain cross-linking reactions.

The prepolymer presented $56.1 \%$ solid and $43.8 \%$ solvent, being higher than values found in the literature [54,55], but like those discussed by Mannari and Massingill [56]. These values indicate a decrease in the amount of volatile organic compounds. The NCO groups is also an important feature for prepolymers, for example, for commercial application normally the NCO groups corresponds to a maximum of $20 \%$ [57] and this work achieved $6.26 \%$. From this index, the required amount of hydrogen donor groups was calculated according to the $\mathrm{NCO} / \mathrm{OH}$ molar ratio studied for each coating.

\section{Attenuated Total Reflectance Fourier Transform Infrared Spectroscopy (FTIR-ATR)}

Figure 6 illustrates the FTIR-ATR spectrum for polyester and prepolymer and the main attributions of the different bands in FTIR-ATR (normalized intensity of bands) stand out.

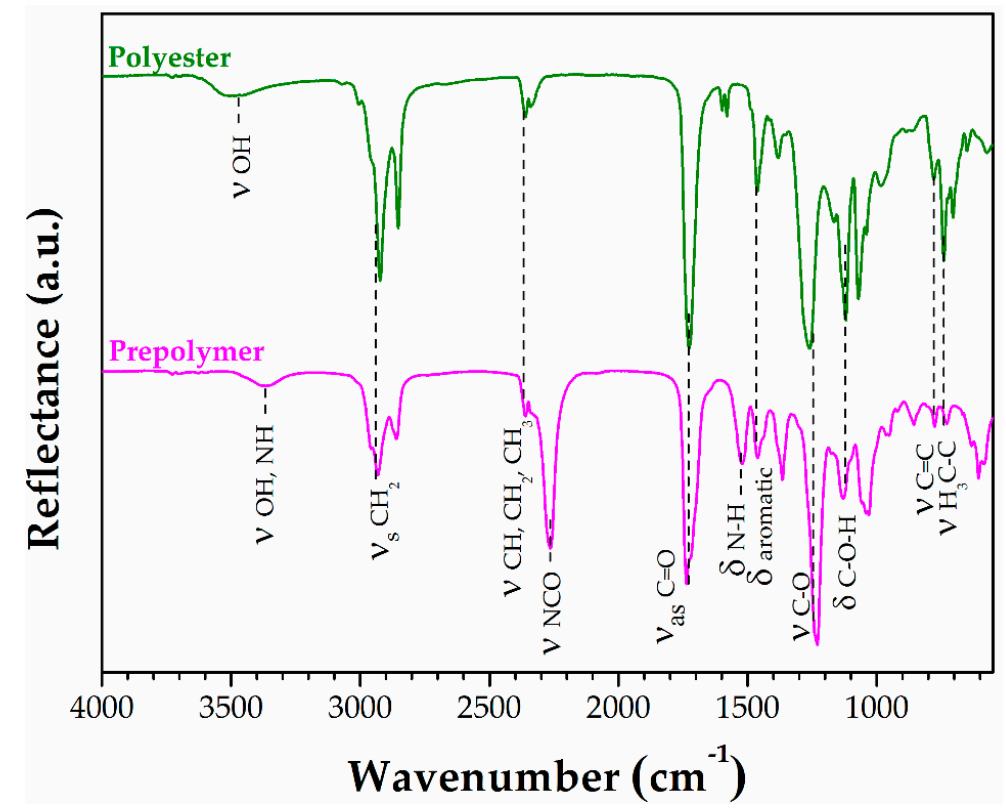

Figure 6. FTIR-ATR spectra for the polyester (-) and prepolymer (-). 
The FTIR-ATR spectrum of polyester confirms the effectiveness of the crambe oil modification reaction (Schemes 2 and 3) by the presence of the $-\mathrm{OH}\left(3489 \mathrm{~cm}^{-1}\right)$ band. The FTIR-ATR spectrum of prepolymer shows the presence of the characteristic $\mathrm{NCO}\left(2270 \mathrm{~cm}^{-1}\right)$ band of free isocyanate groups in the chemical structure (Scheme 4) [58,59].

\subsection{Preparation and Characterization of PU and PU-Modified Resins}

\subsubsection{Preparation of Polyurethane Resins}

Polyester and prepolymer react in the presence of a catalyst, stannous octoate (SO, 1\%), under stirring for $10 \mathrm{~min}$ to produce the PU resin (Figure $5 \mathrm{c}$ and Scheme 5). For the PU-modified resin, steps 1 and 2 were exactly the same as for the reference coating, except that condensed tannin was added $(4.20 \mathrm{~g})$ in the last step of the resin formulation (Figure $5 \mathrm{c}$ and Scheme 6).

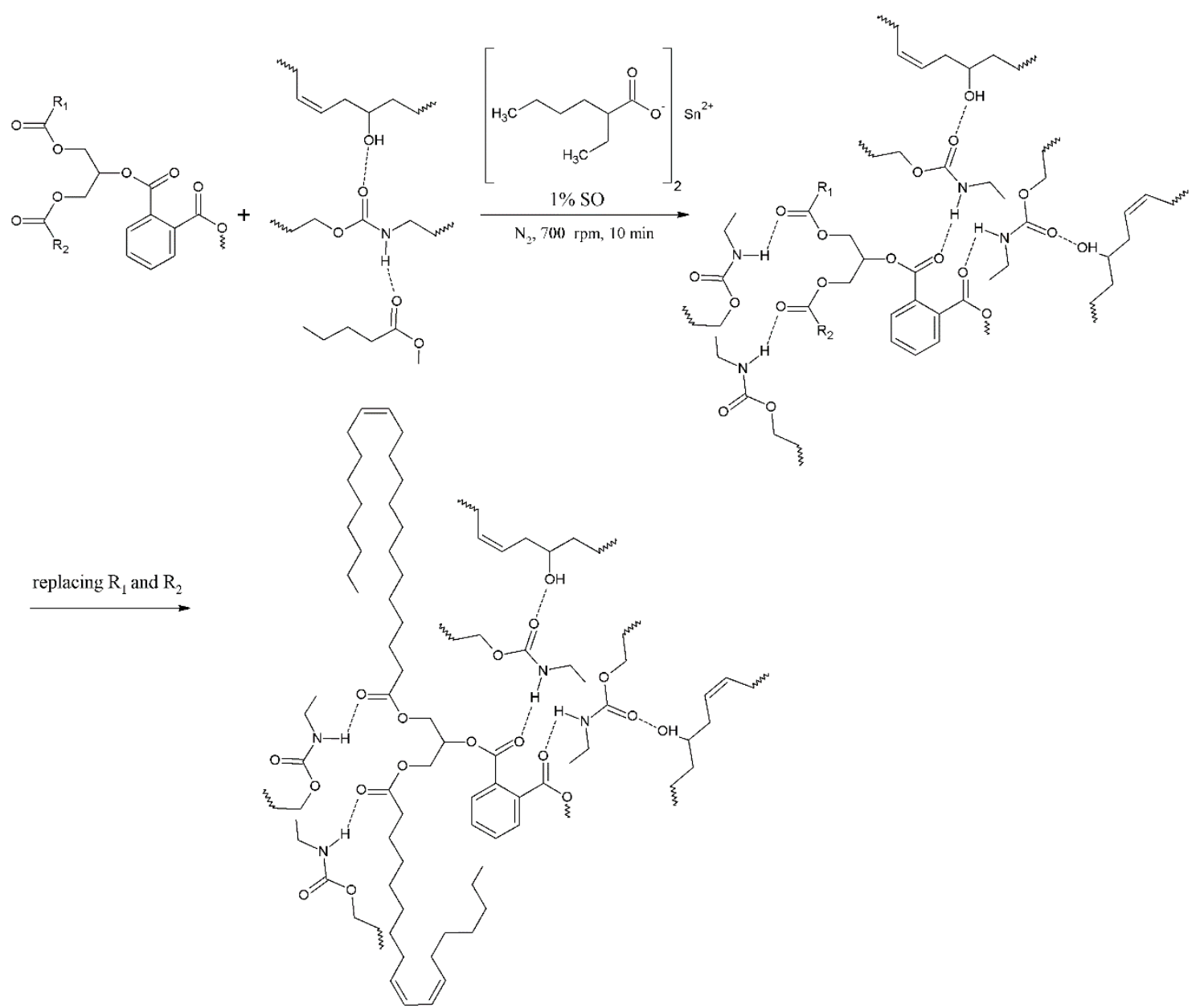

Scheme 5. Preparation of PU-resin. 

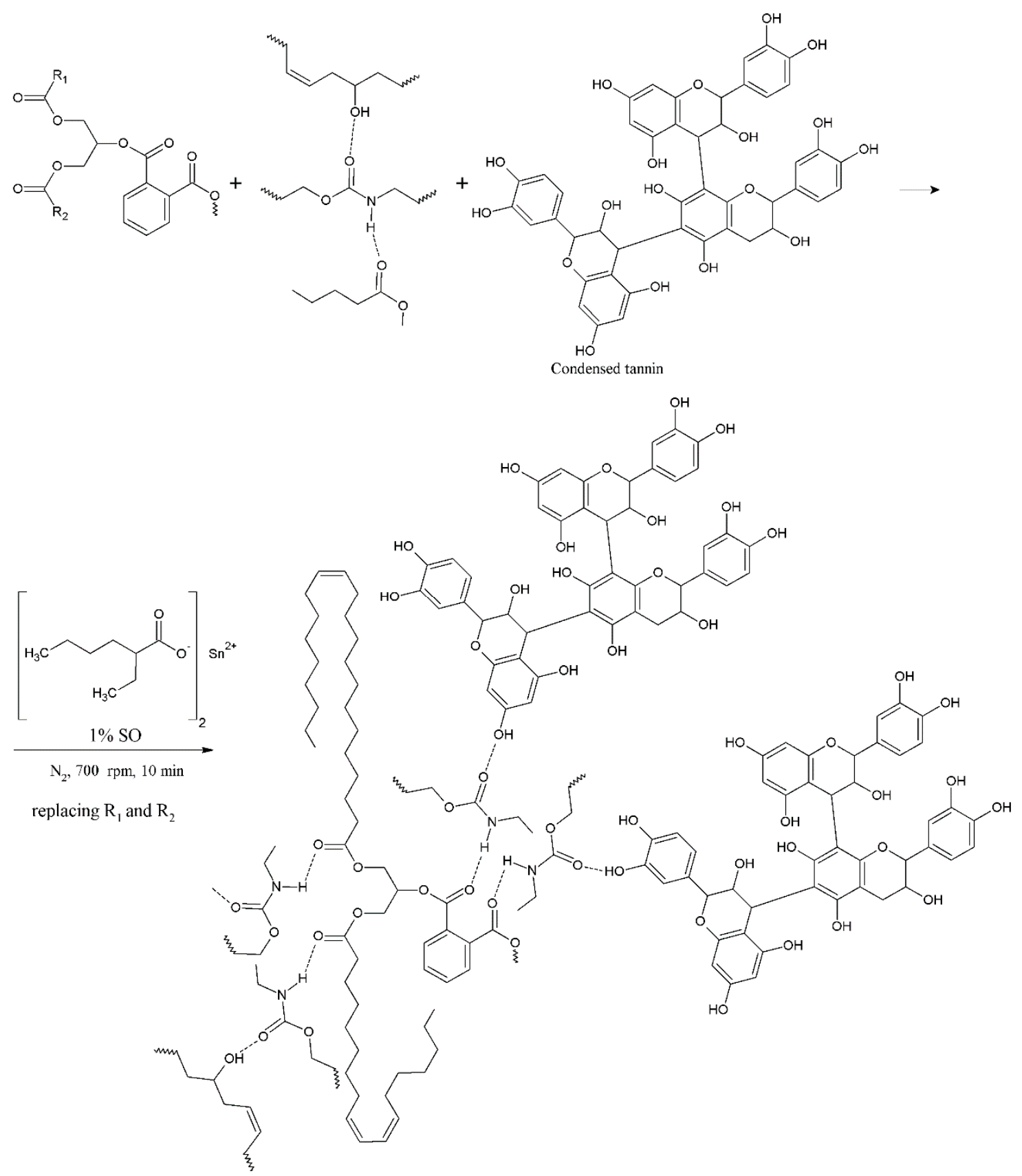

Scheme 6. Preparation of PU-modified resin.

Figure 7 shows a scheme to obtain the monolithic resins. The Teflon sheet substrate was cleaned with deionized water and acetone and allowed to dry $\left(\sim 25^{\circ} \mathrm{C}\right)$. The PU and PU-modified resins formulation was then cast using an applicator on the Teflon sheet substrate. The resin applied on the substrate was kept at room temperature $\left(\sim 25^{\circ} \mathrm{C}\right)$ for $24 \mathrm{~h}$ to allow the solvent to evaporate. 


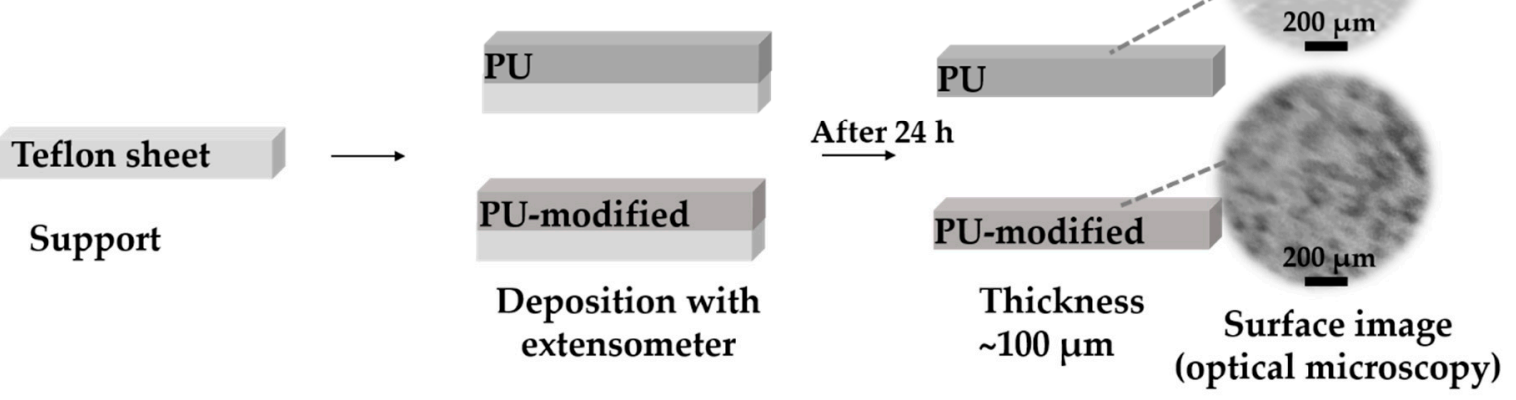

Figure 7. Scheme to obtain the monolithic resins of the PU and PU-modified with condensed tannin.

\subsubsection{Characterization of PU and PU-Modified Resins}

Attenuated Total Reflectance Fourier Transform Infrared Spectroscopy (FTIR-ATR)

Figure 8 illustrates the FTIR-ATR spectrum for PU and PU-modified resins and the main attributions of the different bands in FTIR-ATR (normalized intensity of bands) stand out.

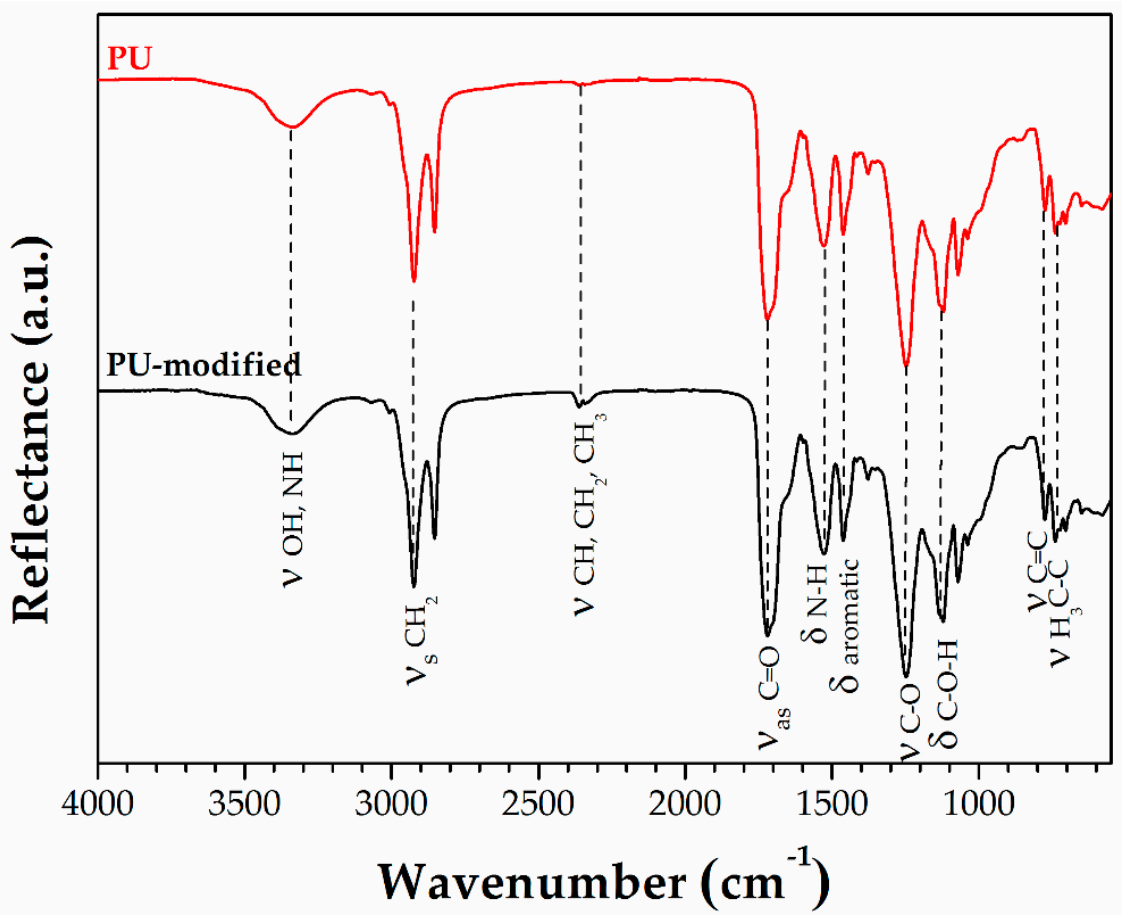

Figure 8. FTIR-ATR spectra for the PU resin (-) and PU-modified resin (一).

In the FTIR-ATR spectrum of PU-resin, it was noted in the band attributed to NCO-free groups that some disappeared, indicating/confirming the complete reaction between the polyester and prepolymer (Schemes 5 and 6) [60]. These spectra are similar, but not the same, as presented by our group in previous studies [43], where the resin was applied on aluminum alloy, and in the present work the monoliths were analyzed. PU and PU-modified resins contain the characteristic bands of $-\mathrm{OH}$ $\left(3346 \mathrm{~cm}^{-1}\right), \mathrm{N}-\mathrm{H}\left(3340\right.$ and $\left.1527 \mathrm{~cm}^{-1}\right), \mathrm{C}=\mathrm{O}\left(1720 \mathrm{~cm}^{-1}\right), \mathrm{C}-\mathrm{O}\left(1249 \mathrm{~cm}^{-1}\right), \mathrm{O}-\mathrm{H}\left(1246 \mathrm{~cm}^{-1}\right)$ and $-\mathrm{O}-\mathrm{H}\left(1120 \mathrm{~cm}^{-1}\right)$ bonds, which clearly show the formation of a urethane linkage [48]. 
Thermogravimetric Analysis (TGA)

Representative dynamic thermogravimetric analysis (TGA) results of PU and PU-modified resins are shown in Figure 9. Table 3 presents the attributions to the mass loss.

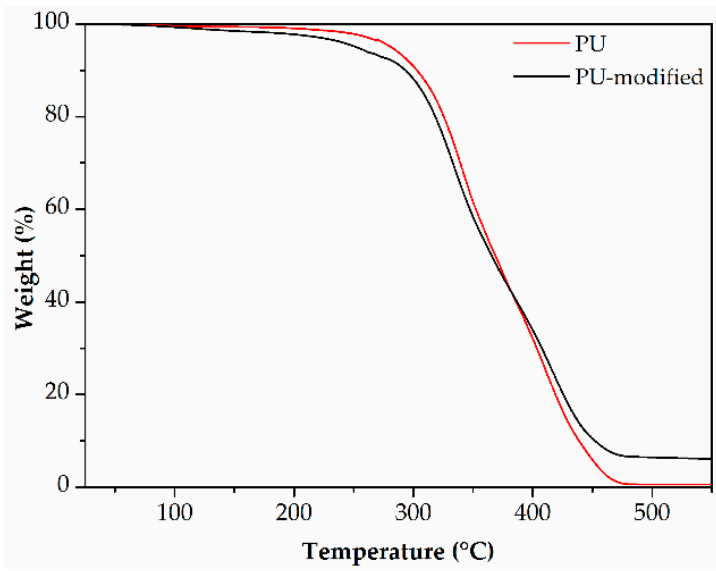

(a)

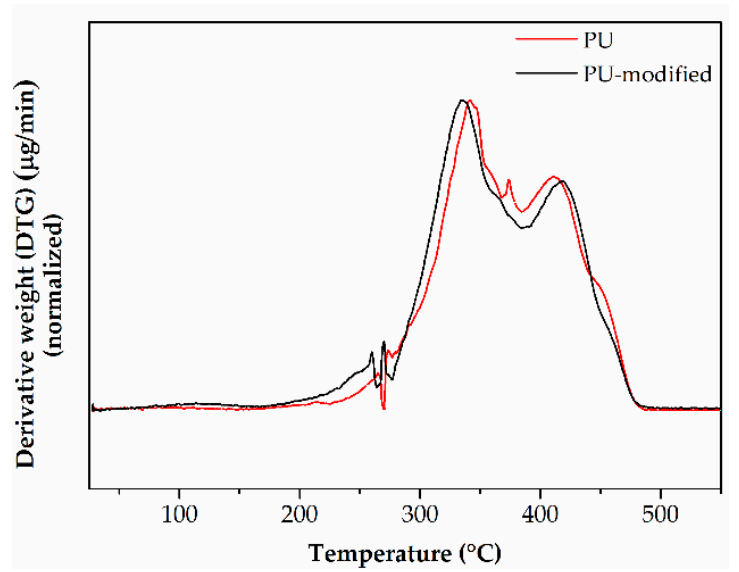

(b)

Figure 9. TGA weight loss (a) and derivatives of TGA data (b) of PU resin (-) and PU-modified resin $(-)$.

Table 3. Attributions to the different thermal events.

\begin{tabular}{ll}
\hline Temperature $\left({ }^{\circ} \mathrm{C}\right)$ & Weight Loss Due to: \\
\hline $260-350$ & Decomposition of active H sources (chain extenders) \\
$360-490$ & Breakup of isocyanate (rigid segment) of the polyester (flexible segment) \\
$200-650$ (two steps) & Decomposition of polyurethane (PU) \\
\hline
\end{tabular}

The PU and PU-modified resins exhibit no significant weight loss before $250{ }^{\circ} \mathrm{C}$, indicating good thermal stability, as already observed for $\mathrm{CO}$ and $\mathrm{CAO}$. Two not well-defined peaks are observed between $\sim 260$ and $\sim 490^{\circ} \mathrm{C}$. The weight loss in the $260-350^{\circ} \mathrm{C}$ range can be referred to the decomposition of chain extensors [61]; in the 360-490 ${ }^{\circ} \mathrm{C}$ interval, the thermal events can be associated with the breakup of prepolymer (rigid segment) of the polyester (flexible segment) [61] and $200-650{ }^{\circ} \mathrm{C}$ (two steps) can be referred to decomposition of polyurethane (PU) to form $\mathrm{CO}_{2}$ and water [62].

\section{Raman Spectroscopy}

Figure 10 shows the Raman spectrum for the resins (normalized for the intensities). 


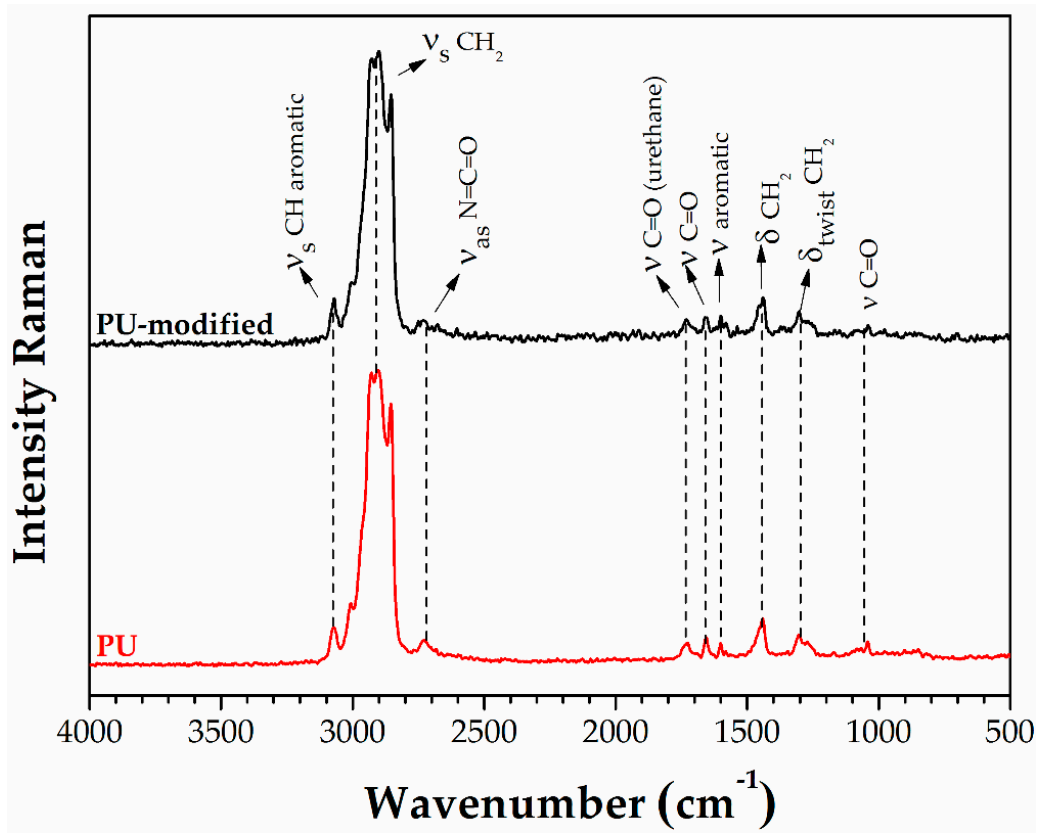

Figure 10. Raman spectra for the PU-blank and PU-modified (with intensity normalized).

Note the presence of some more intense bands, which are characteristic of the formed polymer. The assignments of the bands were made according to previous studies on polyurethanes [63-68].

Artificial Defected Monoliths in Contact with Deionized Water

Figure 11 shows the surface OM images of the PU and the condensed tannin-modified PU monolith obtained before and after immersion in deionized water when an artificial defect was made on the surface.

\section{PU resin}
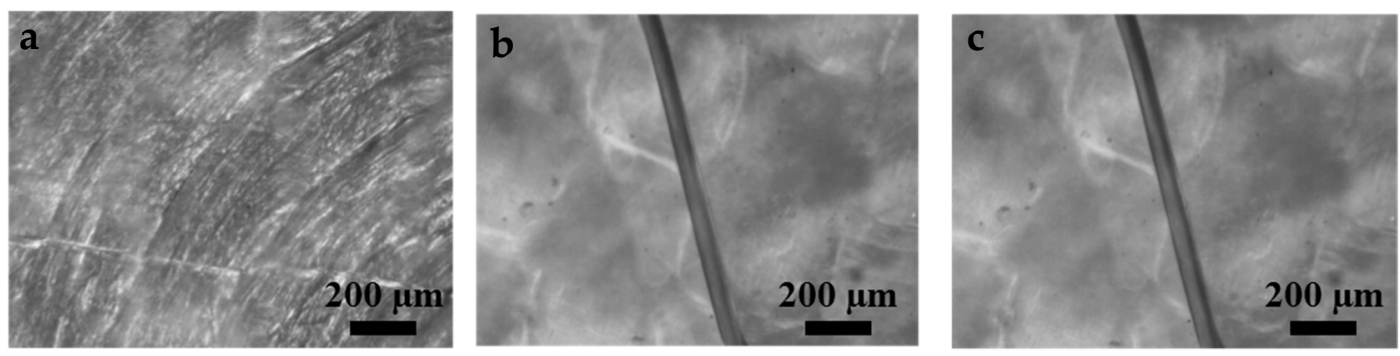

\section{PU-modified resin}
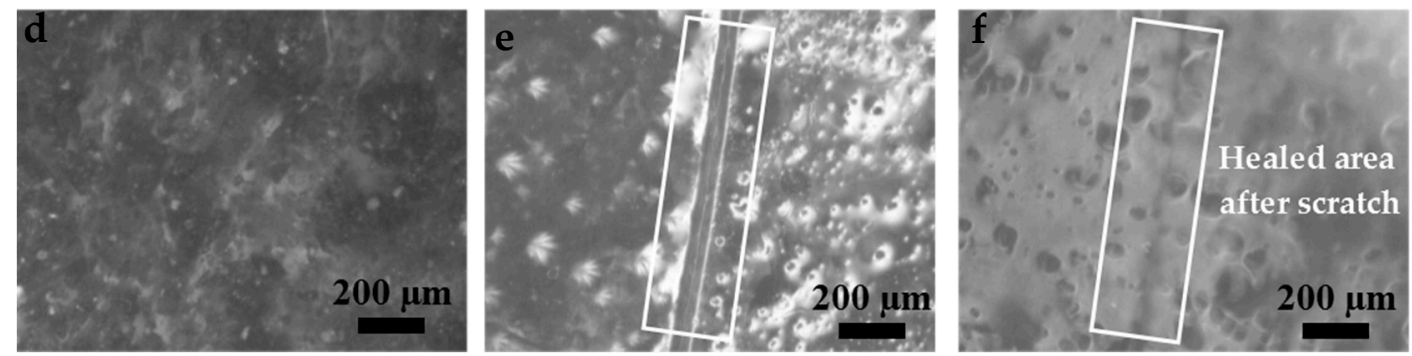

Figure 11. OM images of PU and condensed tannin-modified PU monoliths for the prepared surfaces $(\mathbf{a}, \mathbf{d})$ and after applying an artificial defect before $(\mathbf{b}, \mathbf{e})$ and after $4 \mathrm{~h}$ of immersion in deionized water $(\mathbf{c}, \mathbf{f})$. 
This figure clearly shows that for the PU the defect remained intact after immersion of the monolith in deionized water while for the condensed tannin-modified PU monolith the defect disappeared after some time in contact with deionized water. To demonstrate this process, videos (Figure S1) were recorded of both artificial-defected surfaces during the contact with deionized water for $4 \mathrm{~h}$ and it is clear that the defect remained almost unchanged for PU, while for the modified PU, the defect began to close by the movement of the coating walls limited by the defect until completely closing the defect after some immersion time. Other works have also studied the self-healing effect by microscopic images [59,69-71].

\subsubsection{Self-Healing Effect}

The above-described results (Figure 11 and Figure S1) allow us to propose that the incorporation of condensed tannin in the monolithic resin is responsible for the self-healing effect. The closing of the walls of the artificial defect in a condensed tannin-modified PU monolith was also observed when this type of coating was applied on AA2024 [43]. Tannin-modified PU monolith (100- $\mu \mathrm{m}$ thick) with a scratch of the $1000 \mu \mathrm{m}$ long $\times 60 \mu \mathrm{m}$ wide $\times 100 \mu \mathrm{m}$ deep was automatically repaired when immersed in deionized water. When the modified resin was applied on AA2024, the healing effect was described based on hydrogen bond cleavage, then followed by the formation of a new hydrogen bond and confirmed by electrochemical localized techniques [43]. When tannin-modified PU was placed in contact with water, the swelling of the coating was insignificant, and the self-healing effect was observed, indicating that the self-healing mechanism can be the formation of hydrogen bonds. The FTIR-ATR (Figure 8) suggests an increase of the number of hydrogen bonds after adding condensed tannin to the PU resin. The FTIR-ATR spectrum of the tannin-modified PU monoliths with an artificial defect after having the defect repaired by immersion in water also indicates the increase of the intensity of the band attributed to hydrogen bond, demonstrating that the self-healing effect is based on hydrogen bond generation (Figure 12).

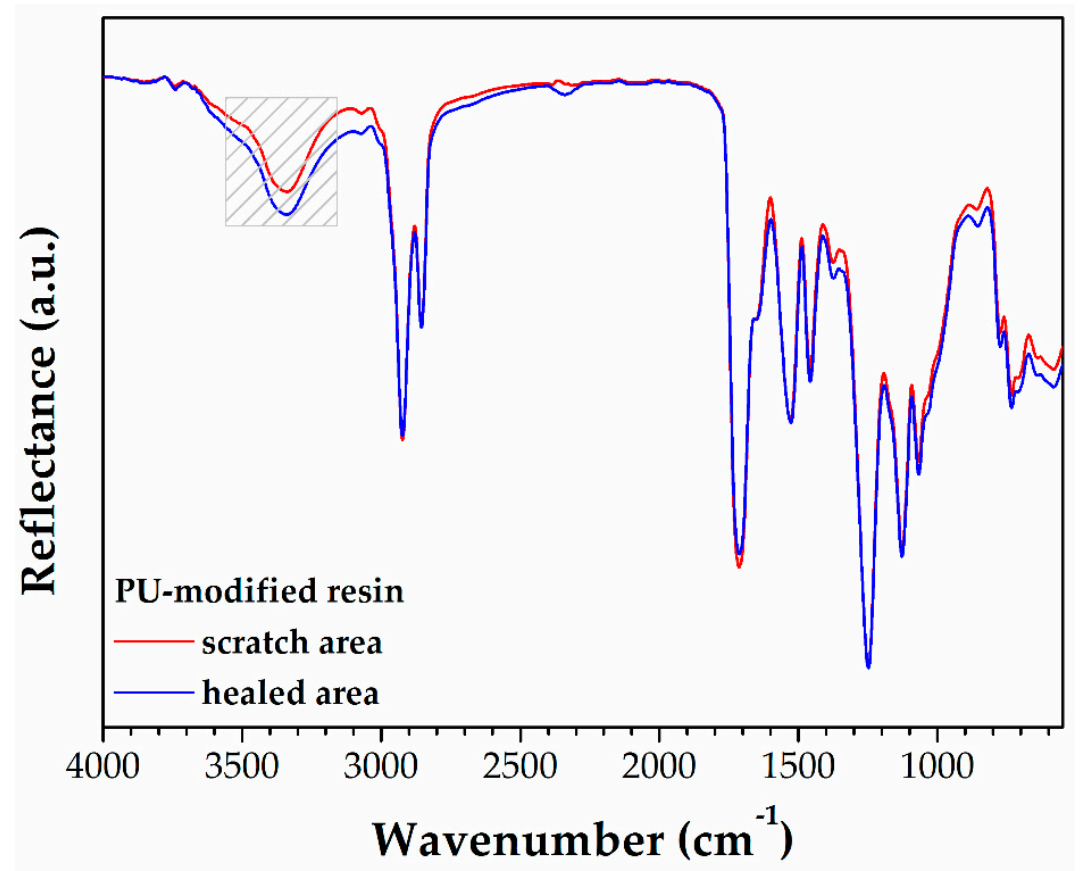

Figure 12. FTIR-ATR spectra of the modified-PU monolith with artificial defect and after having the defect repaired by immersion in water.

It is very important to demonstrate that the self-healing property is a characteristic of the monolith, i.e., a property free of any metallic surface contribution. Therefore, the self-healing effect may be interpreted considering that the free $\mathrm{OH}$ groups present in tannin and some others created in the 
polyurethane by interacting with tannin when in contact with water or humidity allows the formation of new hydrogen bonds. Figure 13 schematizes the possibilities of hydrogen bonding formation between the flexible and rigid segments and condensed tannin.

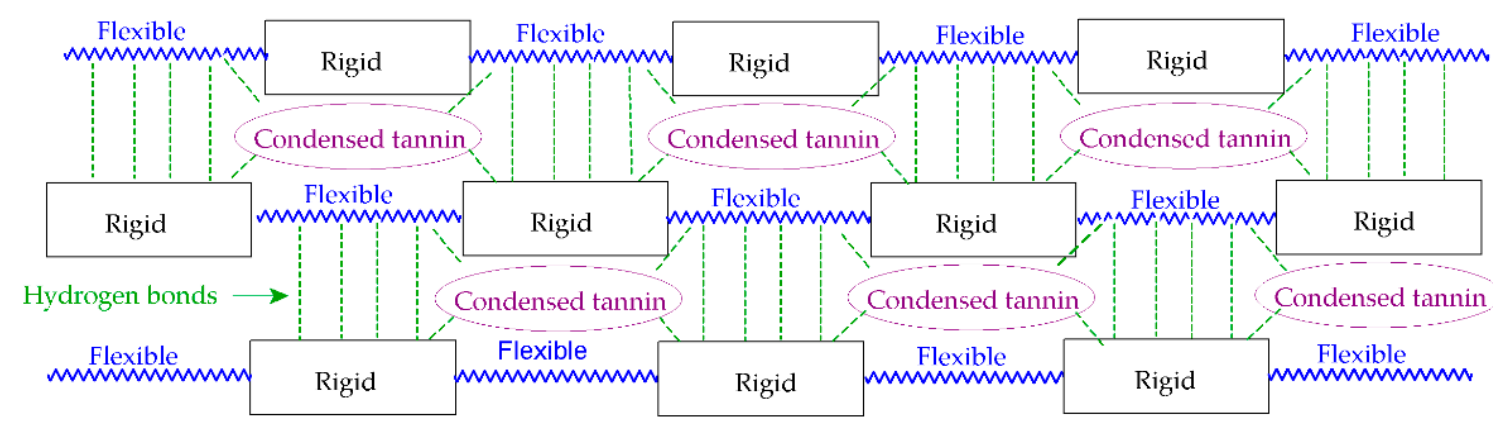

Figure 13. Scheme of hydrogen bonds between flexible and rigid segments of PU and hydrogen bonds between tanning and both segments.

Therefore, the self-healing of the condensed tannin-modified PU coating is understood to function as follows: when an artificial defect or damage is produced on the coating surface, the humidity, water or aqueous solutions rapidly makes new hydrogen bonds-mainly with the tannin and the flexible segment of the polymer. This opens the possibility of hydrogen bond formation with the rigid segment of the polymer; therefore, the healing effect is based on hydrogen bond cleavage followed by new hydrogen bond formation. It is worth remembering that many of the properties of tannins are based on their ability to form hydrogen bonds [51,72]. Interactions involving the formation of new hydrogen bonds between a viscous system (here the polyester, prepolymer and nonmodified resin) in combination with a condensed tannin led to the formation of a flexible structure $[1,73,74]$, mainly due to the greater proportion of polyester, more active than prepolymer, leading to a higher probability to form new hydrogen bonds with condensed tannin.

\subsection{Applications of the PU and PU-Modified Resins}

Special self-healing polyurethane coatings play an important role in the protection of aluminum alloys against corrosion in aggressive aqueous media, mainly in those containing chloride ions [21,22]. Polyurethane-based coatings were applied to protect AA1200 alloy and some formulation offered good barrier effect for 1 year of immersion in $3.5 \mathrm{wt} \% \mathrm{NaCl}$ solution [22].

The resins synthesized in this work were applied on aluminum alloy AA2024-T3 for protecting it against corrosion and the self-healing effect investigated by electrochemical measurements in scratch zone [43]. The efficiency of the incorporation of tannin in the polyurethane resin (condensed tannin-modified PU) was already proved by FTIR-ATR and by the combination of localized electrochemical techniques with surface analysis (in the scratch and scratch-free zones). When immersion in $\mathrm{NaCl} 0.005 \mathrm{~mol} \mathrm{~L}^{-1}$ occurred, the self-healing effect start to act after $2-3 \mathrm{~h}$ and the coating was completely recovered at around $7 \mathrm{~h}$ of immersion in $3.5 \mathrm{wt} \% \mathrm{NaCl}$.

These results open a large window of applications of modified-PU resins in terms of their possible incorporation with other materials with different properties, such as corrosion inhibitors (encapsulated or not), reinforcing materials to increase the wear resistance, materials able to modify the hydrophobicity of the surface and to modify other properties of PU resins. As a consequence, modified-PU resins can be used to extend the lifetime of different metallic surfaces working in aqueous aggressive media or subjects, tribocorrosion conditions, as well as many other applications.

\section{Conclusions}

In this work, polyurethane (PU) produced from vegetable oils and condensed tannin-modified PU resin were successfully obtained and characterized by different chemical and physical techniques. 
The formation of polyester through the modification of the crambe oil was confirmed by the determination of quantity of hydroxyl groups $(151.6 \mathrm{mg} \mathrm{KOH} / \mathrm{g}$ sample) and the prepolymer formation by the disappearance of the free NCO groups of hexamethylene diisocyanate.

FTIR-ATR spectra confirmed that a condensed tannin was used. FTIR-ATR spectra were efficient in confirming the formation of polyester, prepolymer, PU and condensed tannin-modified PU resins, also reinforced by Raman spectra.

The good thermal stability of resins was confirmed by thermogravimetric analysis, since no appreciable weight loss below $250^{\circ} \mathrm{C}$ was observed.

These studies open many possibilities for new vegetable oils-based polyurethane formulations and modified-polyurethane resins that can be used to extend the lifetime of different metallic surfaces, as well as the ability to work in aqueous aggressive media due to the generation of the self-healing property, or to better equip many other applications in materials science.

Supplementary Materials: The following are available online at http://www.mdpi.com/2073-4360/11/11/1890/s1, Figure S1 contains videos a and b.

Author Contributions: Conceptualization, J.V.N. and A.V.B.; methodology, J.V.N.; C.S.F.; E.R.P.P.; W.L.P.; Y.M. and S.J.L.R.; writing — original draft preparation, J.V.N.; writing—review and editing, J.V.N.; S.J.L.R. and A.V.B.; visualization, E.R.P.P.; W.L.P.; Y.M. and S.J.L.R.; supervision, A.V.B.; funding acquisition, J.V.N.

Funding: J.V. Nardeli author thanks the São Paulo state agency FAPESP (Process: 2015/10554-9 and 2018/09040-9) for scholarships.

Acknowledgments: The authors are grateful TANAC S.A. by providing the inhibitors. The authors thank Multiuser Chemical Analysis Laboratory and CEMPEQC of IQ-UNESP the possibility of using the laboratory for analysis FTIR-ATR, Raman and GC-FID; Centro de Química Estrutural, CQE, Instituto Superior Técnico de Lisboa, Portugal the possibility of using the laboratory for termogravimetric analysis. The authors would like to thank Profa. Dra. Isabele Rodrigues Nascimento for the fruitful discussions about organic reactions.

Conflicts of Interest: The authors declare no conflict of interest.

\section{References}

1. Zhu, Y.; Romain, C.; Williams, C.K. Sustainable polymers from renewable resources. Nature 2016, 540, 354-362. [CrossRef] [PubMed]

2. Rahman, M.M.; Rabbani, M.M.; Saha, J.K. Polyurethane and Its Derivatives. In Functional Polymers: Polymers and Polymeric Composites: A Reference Series; Mazumder, J., Sheardown, M.H., Al-Ahmed, A., Eds.; Springer: Cham, Switzerland, 2019. [CrossRef]

3. Szmechtyk, T.; Sienkiewicz, N.; Woźniak, J.; Strzelec, K. Polyurethanes as self-healing materials. Curr. Chem. Lett. 2015, 4, 61-66. [CrossRef]

4. Yang, Z.; Shuai, B.; Zhang, X.; Yu, H.; Zhang, H.; Jia, Y.; Zhang, C.; Guan, X. Fabrication and performance of a polyurethane hybrid composite with waste red mud. Polym. Compos. 2019, 40, 2424-2431. [CrossRef]

5. Khalid, T.; Albasha, L.; Qaddoumi, N.; Yehia, S. Feasibility Study of Using Electrically Conductive Concrete for Electromagnetic Shielding Applications as a Substitute for Carbon-Laced Polyurethane Absorbers in Anechoic Chambers. IEEE Trans. Antenn. Propag. 2017, 65, 2428-2435. [CrossRef]

6. Zhang, C.; Shuai, B.; Zhang, X.; Hu, X.; Zhang, H.; Jia, Y.; Yang, Z.; Guan, X. Polyurethane/Red Mud Composites with Flexibility, Stretchability, and Flame Retardancy for Grouting. Polymers 2018, $10,906$. [CrossRef]

7. Xiang, X.J.; Qian, J.W.; Yang, W.Y.; Fang, M.H.; Qian, X.Q. Synthesis and properties of nanosilica-reinforced polyurethane for grouting. J. Appl. Polym. Sci. 2006, 100, 4333-4337. [CrossRef]

8. Yang, Z.; Zhang, X.; Liu, X.; Guan, X.; Zhang, C.; Niu, Y. Flexible and stretchable polyurethane/waterglass grouting material. Constr. Build. Mater. 2017, 138, 240-246. [CrossRef]

9. Zaimahwati; Yuniati; Jalal, R.; Rihayat, T.; Zhafiri, S. Synthesis and Characterization Thermal of Polyurethane/MMT from Castor Oil Polyols for Coating. Iop Conf. Ser. Mater. Sci. Eng. 2019, 536, 1-8. [CrossRef]

10. Zhao, Z.; Guo, L.; Feng, L.; Lu, H.; Xu, Y.; Wang, J.; Xiang, B.; Zou, X. Polydopamine functionalized graphene oxide nanocomposites reinforced the corrosion protection and adhesion properties of waterborne polyurethane coatings. Eur. Polym. J. 2019, 109249. [CrossRef] 
11. Ye, X.; Wang, Z.; Ma, L.; Wang, Q.; Chu, A. Zinc oxide array/polyurethane nanocomposite coating: Fabrication, characterization and corrosion resistance. Surf. Coat. Technol. 2019, 358, 497-504. [CrossRef]

12. Garrison, T.F.; Kessler, M.R. Chap 3-Plant Oil-Based Polyurethanes, Bio-Based Plant Oil Polymers and Composites; Samy, A., Madbouly, C.Z., Kessler, M.R., Eds.; William Andrew Publishing: Norwich, NY, USA, 2016; pp. 37-54. [CrossRef]

13. Alam, M.; Akram, D.; Sharmin, E.; Zafar, F.; Ahmad, S. Vegetable oil based eco-friendly coating materials: A review article. Arab. J. Chem. 2014, 7, 469-479. [CrossRef]

14. Pfister, D.P.; Xia, Y.; Larock, R.C. Recent advances in vegetable oil-based polyurethanes. Chem. Sus. Chem. 2011, 4, 703-717. [CrossRef]

15. Panda, S.S.; Panda, B.P.; Nayak, S.K.; Mohanty, S. A Review on Waterborne Thermosetting Polyurethane Coatings Based on Castor Oil: Synthesis, Characterization, and Application. Polym. Plast. Technol. Eng. 2018, 57, 500-522. [CrossRef]

16. Gällstedt, M.; Pettersson, H.; Johansson, T.; Newson, W.R.; Johansson, E.; Hedenqvist, M.S. Film Extrusion of Crambe abyssinica/Wheat Gluten Blends. J. Vis. Exp. 2017, 119, e54770. [CrossRef]

17. Rasel, H.; Johansson, T.; Gällstedt, M.; Newson, W.; Johansson, E.; Hedenqvist, M. Development of bioplastics based on agricultural side-stream products: Film extrusion of Crambe abyssinica/wheat gluten blends for packaging purposes. J. Appl. Polym. Sci. 2016, 133, 42442. [CrossRef]

18. Arbenz, A.; Avérous, L. Tannins: A Resource to Elaborate Aromatic and Biobased Polymers. In Biodegradable and Biobased Polymers for Environmental and Biomedical Applications; Susheel, K., Avérous, L., Eds.; Wiley: Hoboken, NJ, USA, 2016; Chapter 4. [CrossRef]

19. Madbouly, S.A.; Otaigbe, J.U. Rheokinetics of thermal-induced gelation of waterborne plyurethane dispersions. Macromolecules 2005, 38, 10178-10184. [CrossRef]

20. Madbouly, S.A.; Xia, Y.; Kessler, M.R. Rheological behavior of environmentally friendly castor oil-based waterborne polyurethane dispersions. Macromolecules 2013, 46, 4606-4616. [CrossRef]

21. Karak, N.; Rana, S.; Cho, J.W. Synthesis and characterization of castor-oil-modified hyperbranched polyurethanes. J. Appl. Surf. Sci. 2009, 112, 736-743. [CrossRef]

22. Nardeli, J.V.; Fugivara, C.S.; Benedetti, A.V. Environmentally Friendly coatings applied on aluminum alloy ASTM 1200. In Proceedings of the 64th Annual Meeting of the International Society of Electrochemistry, Santiago de Querétaro, Mexico, 8-13 September 2013; International Society of Electrochemistry: Lausanne, Switzerland, 2013; Volume 1.

23. Nardeli, J.V.; Fugivara, C.S.; Taryba, M.; Montemor, M.F.; Benedetti, A.V. Zn containing polymer coatings for AA7475: Localized study of anti-corrosion performance. In Proceedings of the the European Corrosion Congress-EUROCORR, Sevilha, Spain, 9-13 September 2019.

24. Nardeli, J.V.; Snihirova, D.V.; Fugivara, C.S.; Montemor, M.F.; Pinto, E.R.P.; Messaddeq, Y.; Benedetti, A.V. Localised corrosion assessement of crambe-oil-based polyurethane coatings applied on the ASTM 1200 aluminum alloy. Corros. Sci. 2016, 111, 422-435. [CrossRef]

25. Talbert, R. Paint Technology Handbook; CRC Press: Boca Raton, FL, USA, 2007; ISBN 9781574447033.

26. Fazenda, J.M.R. Tintas, Ciência e Tecnologia; Abrafati: São Paulo, Brazil, 2009; ISBN 9788521204749.

27. Xie, F.; Zhang, T.; Bryant, P.; Kurusingal, V.; Colwell, J.M.; Laycock, B. Degradation and stabilization of polyurethane elastomers. Prog. Polym. Sci. 2019, 90, 211-268. [CrossRef]

28. Rosu, D.; Rosu, L.; Cascaval, C.N. IR-change and yellowing of polyurethane as a result of UV irradiation. Polym. Deg. Stab. 2009, 94, 591-596. [CrossRef]

29. The Chemistry of Polyurethane Coatings-A General Reference Manual, Bayer ${ }^{\circledR}$ Material Science. Available online: http://digitalcollections.library.cmu.edu/awweb/awarchive?type=file\&item=488891 (accessed on 1 May 2019).

30. Golling, F.E.; Pires, R.; Hecking, A.; Weikard, J.; Richter, F.; Danielmeier, K.; Dijkstra, D. Polyurethanes for corrosion \& adhesives-Chemistry \& applications. Polym. Int. 2019, 68, 848-855. [CrossRef]

31. Hernes, P.J.; Benner, R.; Cowie, G.L.; Goñi, M.A.; Bergamaschi, B.A.; Hedges, J.I. Tannin diagenesis in mangrove leaves from a tropical estuary: A novel molecular approach. Geochim. Cosmochim. Acta 2001, 65, 3109-3122. [CrossRef]

32. Pizzi, A. Tannin-Based Biofoams-A Review. JRM 2019, 7, 477-492. [CrossRef]

33. Tondi, G. Tannin-Based Copolymer Resins: Synthesis and Characterization by Solid State 13C NMR and FT-IR Spectroscopy. Polymers 2017, 9, 223. [CrossRef] 
34. Banu, K.; Shimura, T.; Sadeghi, S. Selective detection and recovery of gold at tannin-immobilized non-conducting electrode. Anal. Chim. Acta 2015, 853, 207-213. [CrossRef]

35. Peres, R.S.; Cassel, E.; Azambuja, D.S. Black wattle tannin as steel corrosion inhibitor. Int. Sch. Res. Net. 2012, 2012, 1-9. [CrossRef]

36. Martinez, S.; Štagljar, I. Correlation between the molecular structure and the corrosion inhibition efficiency of chestnut tannin in acidic solutions. J. Molec. Struc. 2003, 640, 167-174. [CrossRef]

37. Martinez, S. Inhibitory mechanism of mimosa tannin using molecular modeling and substitutional adsorption isotherms. Mater. Chem. Phys. 2002, 77, 97-102. [CrossRef]

38. Michael, N.C.; Olubunmi, J.A. The corrosion inhibition of mild steel in sulphuric acid solution by flavonoid (catechin) separated from Nypa fruticans Wurmb leaves extract. Sci. J. Chem. 2014, 2, 27-32. [CrossRef]

39. Rahim, A.A.; Rocca, E.; Steinmetz, J.; Kassim, M.J.; Adnan, R.; Ibrahim, M.S. Mangrove tannins and their flavanoid monomers as alternative steel corrosion inhibitors in acidic medium. Corros. Sci. 2007, 49, 402-417. [CrossRef]

40. Nardeli, J.V.; Fugivara, C.S.; Taryba, M.; Pinto, E.R.P.; Montemor, M.F.; Benedetti, A.V. Tannin: A natural corrosion inhibitor for bare and coated aluminum alloys. Prog. Org. Coat. 2019, 135, 368-381. [CrossRef]

41. Matamala, G.; Smeltzer, W.; Droguett, G. Comparison of steel anticorrosive protection formulated with natural tannins extracted from acacia and from pine bark. Corros. Sci. 2000, 42, 1351-1362. [CrossRef]

42. Dalmoro, V.; Santos, C.; Santos, J.H.Z. Chap. 20: Smart coatings for corrosion protection. In Industrial Applications for Intelligent Polymers and Coatings; Springer: Berlin, Germany, 2016; pp. 417-435. [CrossRef]

43. Nardeli, J.V.; Fugivara, C.S.; Taryba, M.; Montemor, M.F.; Ribeiro, S.J.L.; Benedetti, A.V. Novel healing coatings based on natural-derived polyurethane modified with tannins for corrosion protection of AA2024-T3. Corros. Sci. 2019, in press. [CrossRef]

44. Fundação MS (Mato Grosso do Sul Foundation for Research and Dissemination of Agricultural Technologies). Available online: http://www.fundacaoms.org.br/ (accessed on 1 May 2019).

45. Grasel, F.S.; Ferrão, M.F. A rapid and non-invasive method for the classification of natural tannin extracts by near-infrared spectroscopy and PLS-DA. Anal. Methods 2016, 8, 644-649. [CrossRef]

46. Peres, R.S.; Armelin, E.; Alemán, C.; Ferreira, C.A. Modified tannin extracted from black wattle tree as an environmentally friendly antifouling pigment. Ind. Crop. Prod. 2015, 65, 506-514. [CrossRef]

47. ASTM E222 Standard Test Methods for Hydroxyl Groups Using Acetic Anhydride Acetylation; American Society for Testing Materials: West Conshohocken, PA, USA, 2010.

48. Alrashed, M.M.; Jana, S.; Soucek, M.D. Corrosion performance of polyurethane hybrid coatings with encapsulated inhibitor. Prog. Org. Coat. 2019, 130, 235-243. [CrossRef]

49. ASTM D2572 Standard Test Method for Isocyanate Groups in Urethane Materials or Prepolymers; American Society for Testing Materials: West Conshohocken, PA, USA, 2010.

50. Alencar, M.A.S.; Benedetti, A.V.; Fugivara, C.S.; Messaddeq, Y. Construção de célula eletroquímica para observação de amostras in situ em estereomicroscópio. Quim. Nova 2010, 33, 1394-1397. [CrossRef]

51. Grasel, F.S.; Ferrão, M.F.; Wolf, C.R. Development of methodology for identification the nature of the polyphenolic extracts by FTIR associated with multivariate analysis. Spectrochim. Acta A Mol. Biomol. Spectrosc. 2016, 153, 94-101. [CrossRef]

52. Pinto, E.R.P. Modificação de óleo Vegetais e de Origem Animal para a Síntese de Poliésteres e Poliuretanos com Baixo teor de Compostos Orgânicos Voláteis. Ph.D. Thesis, Universidade Estadual Paulista Júlio Mesquita Filho (UNESP), Araraquara/SP, Brasil, 2012.

53. Pinto, E.R.P.; Polito, W.L.; Ribeiro, S.J.L.; Messaddeq, Y. Hydroxylated polyester resin synthesizing from crambe oil by mass polymerization. In Proceedings of the 102nd AOCS Annual Meeting \& Expo. 2011, Cincinnati, OH, USA, 1-4 May 2001.

54. Yeganeh, H.; Shamekhi, M.A. Novel polyurethane insulating coatings based on polyhydroxyl compounds, derived from glycolysed PET and castor oil. J. Appl. Polym. Sci. 2006, 99, 1222-1233. [CrossRef]

55. Moeini, H.R. Synthesis and properties of novel polyurethane-urea insulating coatings from hydroxyl-terminated prepolymers and blocked isocyanate curing agent. J. Appl. Polym. Sci. 2009, 112, 3714-3720. [CrossRef]

56. Mannari, V.M.; Massingill, J.L. Two-component high-solid polyurethane coating systems based on soy polyols. J. Coat. Technol. Res. 2006, 3, 151-157. [CrossRef] 
57. Tecnologia dos Poliuretanos. Available online: https://www.poliuretanos.com.br/Cap7/73Tintas.htm (accessed on 1 May 2019).

58. Haghdadeh, P.; Ghaffari, M.; Ramezanzadeh, B.; Bahlakeh, G.; Saeb, M.R. Polyurethane coatings reinforced with 3-(triethoxysilyl)propyl isocyanate functionalized graphene oxide nanosheets: Mechanical and anti-corrosion properties. Prog. Org. Coat. 2019, 136, 105243. [CrossRef]

59. Fan, W.; Zhang, Y.; Li, W.; Wang, W.; Zhao, X.; Song, L. Multi-level self-healing ability of shape memory polyurethane coating with microcapsules by induction heating. Chem. Eng. J. 2019, 368, 1033-1044. [CrossRef]

60. Han, Y.; Hu, J.; Xin, Z. Facile preparation of high solid content waterborne polyurethane and its application in leather surface finishing. Prog. Org. Coat. 2019, 130, 8-16. [CrossRef]

61. Koh, E.; Kim, N.K.; Shin, J.; Kim, Y.W. Polyurethane Microcapsules for Self-Healing Paint Coatings. RSC Adv. 2014, 4, 15830-15834. [CrossRef]

62. Brochu, A.B.; Chyan, W.J.; Reichert, W.M. Microencapsulation of 2-octylcyanoacrylate tissue adhesive for self-healing acrylic bone cement. J. Biomed. Mater. Res. B 2012, 100, 1764-1772. [CrossRef]

63. Miller, C.E.; Archibald, D.D.; Myrick, M.L.; Angel, S.M. Determination of physucal properties of reaction-injection-molded polyurethanes by NIR-FT-Raman spectroscopy. Appl. Spectrosc. 1990, 44, 1297-1300. [CrossRef]

64. Romanova, V.; Begishev, V.; Karmanov, V.; Kondyurin, A.; Maitz, M.F. Fourier transform Raman and Fourier transform infrared spectra of cross-linked polyurethaneurea films synthesized from solutions. J. Raman Spectrosc. 2002, 33, 769-777. [CrossRef]

65. Janik, H.; Palys, B.; Petrovic, Z.S. Multiphase-separated polyurethanes studied by micro-raman spectroscopy. Macromol. Rapid Commun. 2003, 24, 265-268. [CrossRef]

66. Parnell, S.; Min, K.; Cakmak, M. Kinetic studies of polyurethane polymerization with Raman spectroscopy. Polymer 2003, 44, 5137-5144. [CrossRef]

67. Weakley, A.T.; Warwick, P.C.T.; Bitterwolf, T.E.; Aston, D.E. Multivariate analysis of micro-raman spectra of thermoplastic polyurethane blends using principal component analysis and principal component regression. Appl. Spectrosc. 2012, 66, 1269-1278. [CrossRef] [PubMed]

68. Bruckmoser, K.; Resch, K. Investigation of ageing mechanisms in thermoplastic polyurethanes by means of IR and Raman spectroscopy. Macromol. Symp. 2014, 339, 70-83. [CrossRef]

69. Navarchian, A.H.; Najafipoor, N.; Ahangaran, F. Surface-modified poly(methyl methacrylate) microcapsules containing linseed oil for application in self-healing epoxy-based coatings. Prog. Org. Coat. 2019, 132, 288-297. [CrossRef]

70. Khan, A.; Ubaid, F.; Fayyad, E.M.; Ahmad, Z.; Shakoor, R.A.; Montemor, M.F.; Kahraman, R.; Mansour, S.; Hassan, M.K.; Hasan, A.; et al. Synthesis and properties of polyelectrolyte multilayered microcapsules reinforced smart coatings. J. Mater. Sci. 2019, 54, 12079-12094. [CrossRef]

71. Chaudhari, A.B.; Tatiya, P.D.; Hedaoo, R.K.; Kulkarni, R.D.; Gite, V.V. Polyurethane Prepared from Neem Oil Polyesteramides for Self-Healing Anticorrosive Coatings. Ind. Eng. Chem. Res. 2013, 52, 10189-10197. [CrossRef]

72. Hailong, F.; Wang, J.; Jin, Z. Tough, Swelling-Resistant, Self-Healing, and Adhesive Dual-Cross-Linked Hydrogels Based on Polymer-Tannic Acid Multiple Hydrogen Bonds. Macromolecules 2018, 51, 1696-1705. [CrossRef]

73. Burattini, S.; Colquhoun, H.M.; Fox, J.D.; Friedmann, D.; Greenland, B.W.; Harris, P.J.F.; Hayes, W.; Mackay, M.E.; Rowan, S.J. A self-repairing, supramolecular polymer system: Healability as a consequence of donor-acceptor $\pi-\pi$ stacking interactions. Chem. Commun. 2009, 44, 6717-6719. [CrossRef]

74. Mauldin, T.C.; Kessler, M.R. Self-healing polymers and composites. Int. Mater. Rev. 2010, 55, 317-346. [CrossRef]

(C) 2019 by the authors. Licensee MDPI, Basel, Switzerland. This article is an open access article distributed under the terms and conditions of the Creative Commons Attribution (CC BY) license (http://creativecommons.org/licenses/by/4.0/). 